\title{
Cheatgrass and yellow starthistle growth at 3 soil depths
}

\author{
ROGER L. SHELEY AND LARRY L. LARSON
}

Authors are assistant professor, Department of Plant, Soil and Environmental Sciences, Montana State University, Bozeman, Mont. 59717; and associate professor, Department of Rangeland Resources, Oregon State University, Corvallis, stationed at OSU-EOSC Agriculture Program, Eastern Oregon State. College, La Grande, Ore. 97850.

\begin{abstract}
Community dynamics and dominance on cheatgrass (Bromus tectorum L.) and yellow starthistle (Centaurea solstitialis L.) infested rangeland appear to be influenced by resource acquisition rates and duration of growth. Objectives were to determine the effects of densities, proportions, and soil depth on the growth rate and duration of growth of these species. In 6 field experiments isolated individuals, monocultures $(100,1,000,10,000$ plants $\mathbf{m}^{-2}$ ), and mixtures (same densities arranged factorially) were grown with unrestricted and restricted $(0.2-$ and $0.5-\mathrm{m})$ soil depths. Shoot weights were determined on 12-day intervals beginning on day 24 and ending on day 72 for plants grown with restricted soil depth and day 96 (cheatgrass) and day 108 (yellow starthistle) for plants grown in unrestricted soil. Quadratic growth curves were fit for each replication for plants grown in isolation. Linear and quadratic models were developed for plants grown in monocultures and mixtures. Simple linear regression coefficients were used as growth rates and regressed over plant density. Time of inflection (an indicator of the duration of growth) for plants growing in monocultures and mixtures was calculated from quadratic models. Growth rate of yellow starthistle was about 7 times faster and duration of growth 25 days longer, than those of cheatgrass when grown in isolation without soil depth restriction. As densities were increased and/or soil depth decreased, growth rate and duration of growth were lowered and the difference between species were masked. Growth rates and duration of growth of cheatgrass and yellow starthistle appear to depend on plant density, soil depth, and available soil moisture.
\end{abstract}

Key Words: Centaurea solstitialis, Bromus tectorum, growth rates, growth duration, community dynamics, rangeland weeds.

Cheatgrass (Bromus tectorum L.) and yellow starthistle (Centaurea solstitialis L.) co-dominate over 250 thousand hectares of rangeland throughout the Pacific Northwest. These winter annual species arrived in North America near the turn of the century from the steppes of Eurasia. Cheatgrass, an early maturing forage, dominated most disturbed steppe communities in the Intermountain West by 1930 (Mack 1981). Since 1920, yellow starthistle, a noxious weed, has invaded cheatgrass infest-

Research funded by the National Park Service Grant CA 9000800006-13. Published as Oregon Agr. Exp. Tech. Paper No. 10297.

Manuscript accepted 23 Apr. 1996 ed rangeland (Maddox and Mayfield 1985, Sheley et al. 1993). In many areas, these species have replaced perennial grass communities thereby reducing resource values (Callihan et al. 1989).

Understanding mechanisms that govern community dynamics is central to the management of rangelands dominated by alien annuals (Sheley et al. 1996). Hironaka (1989) suggested that among winter annuals, early maturing species would tend to be replaced by later maturing ones. However, shifts in community dominance between cheatgrass and yellow starthistle appear to be more complex and oscillatory (Sheley and Larson 1994a). Dominance within cheatgrass and yellow starthistle communities tend to reflect resource availability and its impact upon growth and seed production (Sheley and Larson 1994a). Species differentiation within these communities is strongly influenced by the ability of yellow starthistle to attain greater root penetration than cheatgrass (Sheley et al. 1993, Roché et al. 1994, Sheley and Larson 1994a, 1994b). Consequently, edaphic conditions that restrict soil depth penetration alter the competitive advantage in favor of the relatively shallow and fibrous rooted cheatgrass (Sheley and Larson 1995).

Resource acquisition rates and duration appear to influence cheatgrass and yellow starthistle dynamics. The objectives of this study were to compare the growth rate and the duration of growth between cheatgrass and yellow starthistle at various densities, species proportions, and soil depths.

\section{Materials and Methods}

Field studies were conducted during 1992 in southeastern Washington $\left(46^{\circ} 01^{\prime} \mathrm{N}, 118^{\circ} 27^{\prime} \mathrm{W}\right)$ at an elevation of $320 \mathrm{~m}$. The study site lies within the bluebunch wheatgrass (Pseudoroegneria spicata (Pursh) Scribn. \& Smith) - Idaho fescue (Festuca idahoensis Elmer) habitat type (Daubenmire 1970). Vegetation was predominantly cheatgrass and yellow starthistle. The soil is a Walla Walla silt loam (coarse-silty, mixed, mesic Typic Haploxeroll), developed from thick loess redeposited with glacial outwash material over basalt. Annual precipitation averages 380 Inm with a binodal distribution pattern that peaks during the winter and spring. Temperatures range from -34 to $45^{\circ} \mathrm{C}$ with an average frost-free season of 170 days.

Temperature, precipitation, and evaporation were monitored daily from October 1991 through June 1992. Environmental data collected prior to the initiation of the study (October-February) and during the study (March-June) are summarized in Table 1. 
Table 1. Environmental conditions at the study site. ${ }^{1}$

\begin{tabular}{|c|c|c|c|c|}
\hline \multirow{2}{*}{$\begin{array}{l}\text { Time } \\
\text { Period }\end{array}$} & \multirow{2}{*}{$\begin{array}{c}\text { Total } \\
\text { precipitation }\end{array}$} & \multirow{2}{*}{$\begin{array}{c}\text { Total } \\
\text { evaporation }\end{array}$} & \multicolumn{2}{|c|}{ Mean temperature } \\
\hline & & & $\max$. & $\min$ \\
\hline \multicolumn{5}{|l|}{ Prestudy } \\
\hline Oct. 1991 & 51 & ${ }^{2}$ & 20.0 & 0.6 \\
\hline Nov. & 80 & & 8.4 & 1.1 \\
\hline Dec. & 16 & & 4.5 & -0.6 \\
\hline Jan. 1992 & 19 & & 8.1 & 0.2 \\
\hline Feb. & 29 & & 10.6 & -0.2 \\
\hline \multicolumn{5}{|l|}{ Study } \\
\hline $12 \mathrm{Mar}$ & 5 & - & 13.3 & 0.8 \\
\hline 24 Mar. & 4 & 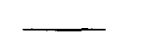 & 18.0 & 1.2 \\
\hline 5 Apr. & 0 & & 18.9 & 1.9 \\
\hline 17 Apr. & 22 & 27 & 17.1 & 5.2 \\
\hline 29 Apr. & 0 & 57 & 24.1 & 6.4 \\
\hline 11 May & 11 & 72 & 24.7 & 6.0 \\
\hline 23 May & 1 & 77 & 24.6 & 4.9 \\
\hline 4 Jun. & 6 & 88 & 29.4 & 14.4 \\
\hline 16 Jun. & 15 & 78 & 26.1 & 9.4 \\
\hline 28 Jun. & 2 & 115 & 34.7 & 15.9 \\
\hline
\end{tabular}

${ }^{1}$ Monthly values are presented for the 5 months preceding the study. Twelve day values are presented to correspond with harvest dates.

${ }^{2}$ Evaporation data were not collected during periods of freezing temp.

\section{Growth Without Soil Depth Restriction}

In study 1 , growth comparisons of isolated individuals, monoculturcs, and mixtures of cheatgrass and yellow starthistle were made with unrestricted soil depths. In experiment 1 , isolated $\left(0.25 \mathrm{~m}^{2}\right.$ plant $\left.^{-1}\right)$ individuals of cheatgrass and yellow starthistle were grown for each of 8 harvest dates ( 2 species, 4 replications). For experiment 2, monocultural plant densities were 100, 1,000, and 10,000 plants $\mathrm{m}^{-2}$ for each species ( 2 species, 3 densities, 4 replications). In experiment 3 , densities were factorially arranged ( 9 density combinations, 4 replications) for mixtures. Each cxperiment conformed to a randomized-complete-block design.

\section{Growth With Soil Depth Restriction}

In study 2 , the objective was to assess growth with limited soil depth on cheatgrass and yellow starthistle. Prior experiments were repeated with soil profiles restricted to $0.2-\mathrm{m}$ (shallow soil depth) and $0.5-\mathrm{m}$ (moderate soil depth) by placing an 8 -mil impermeable plastic liner $(9 \times 0.7 \mathrm{~m})$ below the soil surface. Experiments were replicated 4 times in a split-plot design with soil depth as wholeplots and plant density (isolated, monocultures, mixtures) as subplots.

\section{Procedures}

Seeds for all experiments were collected on site during the fall of 1991 and stored at room temperature. Seeds were sown on 29 Feb. and 1 Mar. 1992, in $0.25-\mathrm{m}^{2}$ (isolated) and $0.5-\mathrm{m}^{2}$ (monocultures and mixtures) plots to avoid winter seedling mortality. Seeds were randomly broadcast, then hand separated with forceps until uniform distance between seeds was achieved. Seeds were lightly $(<2 \mathrm{~mm}$ ) covered with soil. Plants were thinned by hand to the appropriate density 1 week after emergence. Plots with densities of 10,000 plants $\mathrm{m}^{-2}$ did not require thinning.

An individual plant of each species on each plot was chosen randomly, then clipped to ground level, on 12-day intervals beginning 24 days after planting. Final harvest dates for experi- ments that did not restrict soil depth occurred on day 96 for cheatgrass and day 108 for yellow starthistle. Final harvests for experiments with soil depth restrictions occurred 72 days after planting for both species. Shoots were dried for 48 hours at $60^{\circ} \mathrm{C}$ and weighed $(\mathrm{mg})$.

\section{Plant Moisture Stress}

Predawn xylem pressure potential (MPa) was measured on a representative plant from each plot in each experiment on 14 and 15 May 1992 using a pressure chamber (PMS Inc., Corvallis, Ore.). Cheatgrass plants were in the 2- to 4-leaf stage, and yellow starthistle plants were in the rosette growth stage. An equipment malfunction while collecting data in block 1 resulted in unreliable data. Data from blicks 2 to 4 were analyzed and are presented.

\section{Analysis}

The relationship between shoot weight and time after planting was detcrmincd by regression. Coefficicnts of detcrmination, residual mean squares, sum of squares, and residuals were evaluated to deternine the most suitable model for the prediction of accumulated shoot weiglıt over time (Hunt 1982, France and Thornley 1984). Quarratic models provided the bcst estimate for plants grown in isolation, and linear models provided the best fit for monocultures and mixtures. Data were incorporated into least squares regression models of the form:

$$
\begin{array}{ll}
\text { Quadratic model: } & \hat{y}=\beta_{0}+\beta_{1} x_{1}+\beta_{2} X_{1}{ }^{2} \\
\text { Linear model: } & \hat{y}=\beta_{0}+\beta_{1} X_{1}
\end{array}
$$

where $\hat{y}$ is the shoot weight $(\mathrm{mg})$ and $X$ is time in days. Regression coefficients $\beta_{0-2}$ are the line intercept, linear, and quadratic components of the regression equation, respectively.

Quadratic models for plants grown in isolation were determined for each treatment in each replication. Time of inflection $(T)$, point of inflection $(P)$, and relative growth rate (RGR) were calculated using the linear and quadratic regression coefficients derived from growth curves. Time of inflection is the date when the absolute growth rate (AGR) was most rapid and provides an indication of duration of growth. Point of inflection is the shoot weight at the time of maximum growth rate. Relative growth rate, an index of growth efficiency, was calculated at 36,60, and 84 days after planting. Absolute growth rates were determined for the early ( 24 to 48 days after planting), midule (48 to 72 days after planting) and late (72 to 96 days after planting) growth periods. Growth rates for late growth periods were only calculated for treatments without soil depth restriction. Calculation of these parameters were as follows:

$$
\begin{gathered}
T=\frac{\beta_{1}}{2 \beta_{2}}-\frac{1}{\left(-2 \beta_{2}\right)^{0.5}} \\
P=E X P\left(\beta_{1}\left(\beta_{2} \mathrm{~T}\right)+\beta_{2} T^{2}\right) \\
R G R=\beta_{1}+2 \beta_{2}+\mathrm{t} \\
A G R=\frac{\mathrm{W}_{2}-\mathrm{W}_{1}}{\mathrm{t}_{2}-\mathrm{t}_{1}}
\end{gathered}
$$

where $\beta_{1}$ is the linear and $\beta_{2}$ the quadratic regression coefficient, $t$ is time, and $W_{1}$ and $W_{2}$ are the initial and finct plant weight, corresponding to $t_{1}$ and $t_{2}$. 
Table 2. Growth of cheatgrass and yellow starthistle grown in isolation with and without soil depth restrictions.

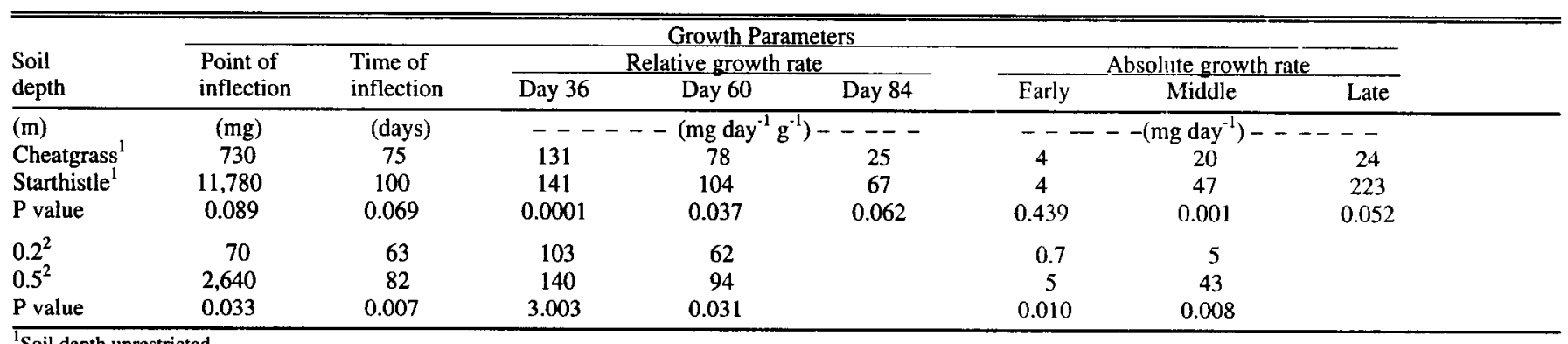

Soil depth unrestricted.

${ }^{2}$ Soil depth restriction - Combined means are presented.

Differences among mean time of inflection, point of inflection and growth rates were tested by analysis of variance. Probability values are provided to indicate level of mean separations.

Regression models of shoot weight accumulation were calculated using both simple linear and curvilinear regression for plants grown in monocultures and mixtures. Time of inflection (duration of growth) for plants grown in mixtures was calculated from quadratic models. Linear models were developed by regressing shoot weight over the duration of the experiment and produced a $\beta$ coefficient. We considered the $\beta$ coefficient an estimate of the shoot growth rate. Differences between mean growth rates due to soil depth (0.2- and 0.5-m) and time of inflection for monoculture and mixtures were tested by analysis of variance.

Growth rate data derived from simple linear regression were incorporated into multiple linear regression models using least squares regression of the form:

$$
\begin{aligned}
& w_{c}=\beta_{c o}+\beta_{c c} \log N_{c}+\beta_{c y} \log N_{y} \\
& w_{y}=\beta_{y o}+\beta_{y y} \log N_{y}+\beta_{y c} \log N_{c}
\end{aligned}
$$

where $W_{c}$ and $W_{y}$ were the average shoot growth rate for cheatgrass and yellow starthistle, respectively, and $\mathrm{N}_{c}$ and $\mathrm{N}_{\mathrm{y}}$ were their density. Regression coefficients $\beta_{\text {co }}$ and $\beta_{\text {yo }}$ estimate the growth rate for an isolated individual. Regression coefficients $\beta_{\mathrm{cc}}$ and $\beta_{y y}$ estimate intraspecific interaction and $\beta_{c y}$ and $\beta_{y c}$ estimate interspecific interaction. Ratios $\beta_{\mathrm{cc}}: \beta_{\mathrm{cy}}$ and $\beta_{\mathrm{yy}}: \beta_{\mathrm{yc}}$ determine the relative influence of each species density on their growth rates.

\section{Results}

\section{Environmental Conditions}

Cummulative precipitation during the 5 months prior to the study amounted to $195 \mathrm{~mm}$. An additional $63 \mathrm{~mm}$ of precipitation occurred during the 4-month study period (Table 1). By comparison, average precipitation ( 59 years) for the 4-month study period is $218 \mathrm{~mm}$. Below average spring precipitation is expected to occur 4 years out of 10. Precipitation during March, April, May, and June is predicted to be less than $15,10,10$, and $5 \mathrm{~mm}$, respectively, once in 10 years. Months with the lowest and highest mean temperatures were December $\left(4.5^{\circ} \mathrm{C}\right)$ and June $\left(34.7^{\circ} \mathrm{C}\right)$, respectively. Several unusually warm $\left(19^{\circ} \mathrm{C}\right)$ days occurred during March 1992. December and February minimum mean temperatures were below freezing.

\section{Growth of Isolated Individuals}

Isolated yellow stathistle grow'th exceeded that of cheatgrass for all parameters $(\mathrm{P} \leq 0.10)$ when grown without soil depth restriction (Table 2). Early season absolute growth rate was similar for both species, then separated during the latter two-thirds of the growing season. These results are consistent with other cheatgrass and yellow starthistle growth comparisons (Sheley and Larson 1994b).

Restricting soil depth from $0.5-$ to $0.2-\mathrm{m}$ reduced growth of isolated plants and masked species differences (Table 2). Relative growth rates $\left(\mathrm{mg} \mathrm{day}^{-1} \mathrm{~g}^{-1}\right)$ for yellow starthistle on day 36 $(P=0.075)$ and $60(P=0.026)$ were greater than those of cheatgrass.

\section{Growth of Individuals in Monocultures}

Beta coefficients derived from simple linear regression indicate that increases in density decreased the growth rate of cheatgrass and yellow starthistle (Table 3). Monoculture density accounted for over $60 \%$ of the growth rate variation.

Predicted growth rate was 5-fold greater for isolated yellow starthistle growing in unrestricted soil when compared to cheatgrass (Table 3 ). Increasing cheatgrass and yellow starthistle density 10 -fold reduced their growth rate 7.6 and $48 \mathrm{mg} \mathrm{day}^{-1}$, respectively. Restricting soil depth to $0.5-\mathrm{m}$, reduced yellow starthistle's growth rate almost 3-fold, but increased the growth rate of cheatgrass. Increasing monocultural densities 10 -fold reduced growth rates of cheatgrass $11 \mathrm{mg} \mathrm{day}^{-1}$ and yellow starthistle $13 \mathrm{mg}$ day $^{-1}$. Restricting soil depth to $0.2-\mathrm{m}$, reduced growth rates to less than $7 \mathrm{mg} \mathrm{day}^{-1}$.

Table 3. Simple linear regression analysis for predicting ${ }^{1}$ cheatgrass (Wc) and yellow starthistle (Wy) shoot growth rates ( $\mathrm{mg} \mathrm{day}^{-1}$ ) grown in monocultures with and without soil depth restrictions.

\begin{tabular}{llccc}
\hline \hline Species & S $r$ il depth & $\beta_{\mathrm{o}}{ }^{2}$ & $\beta_{1}{ }^{2}$ & $\mathrm{R}^{2}$ \\
\hline Cheatgrass & Unrestricted & 30.3 & -7.6 & 0.68 \\
& $0.5 \mathrm{~m}$ & 43.3 & -10.9 & 0.92 \\
& $0.2-\mathrm{m}$ & 4.0 & -1.0 & 0.67 \\
\multirow{4}{*}{ Starthistle } & Unrestricted & 150.8 & -47.6 & 0.84 \\
& $0.5-\mathrm{m}$ & 53.6 & -13.3 & 0.94 \\
& $0.2-\mathrm{m}$ & 6.5 & -1.7 & 0.61 \\
\hline
\end{tabular}

${ }^{\mathrm{T}} \mathrm{W}_{\mathrm{c}}=\beta_{\mathrm{co}}+\beta_{\mathrm{cc}} \mathrm{N}_{\mathrm{c}}$

$\mathrm{w}_{\mathrm{y}}=\beta_{\mathrm{yo}}+\beta_{\mathrm{yy}} \mathrm{N}_{\mathrm{y}}$
$\mathrm{cos}$

${ }^{2} \beta_{\mathrm{to}}$ is the estimated grouth rate of an isolated individual. $\beta_{1}$ is the effect of increasing monocultural densities on growth rate. 
Table 4. Effect of soil depth and density on the time of inflection' for cheatgrass and yellow starthistle grown in monocultures.

\begin{tabular}{|c|c|c|c|c|}
\hline \multirow[b]{2}{*}{ Soil depth } & \multicolumn{3}{|c|}{ Density (plants $\mathrm{m}^{-2}$ ) } & \multirow[b]{2}{*}{$\operatorname{LSD}_{(0.05)}$} \\
\hline & 100 & 1,000 & 10,000 & \\
\hline (m) & $\ldots$ & (days & $\cdots$ & \\
\hline Cheatgrass $^{2}$ & 81 & 84 & 57 & $11^{3}$ \\
\hline Starthistle $^{2}$ & 108 & 69 & 62 & \\
\hline $0.2^{4}$ & 80 & 53 & 57 & $9^{3}$ \\
\hline $\begin{array}{l}0.5^{4} \\
\operatorname{LSD}_{(0.05)}\end{array}$ & 84 & $\begin{array}{l}73 \\
11^{5}\end{array}$ & 49 & \\
\hline
\end{tabular}

'Time of inflection is an indicator of duration of growth.

${ }^{2}$ Soil depth unrestricted.

${ }^{3}$ Comparing species or depth within each density.

${ }^{4}$ Soil depth restriction-combined means are presented.

'Comparing density within each depth.

Based on time of inflection, the duration of growth for yellow starthistle was 27 days longer than cheatgrass when grown in monocultures of 100 plants $\mathrm{m}^{-2}$ without soil depth restriction (Table 4). Increasing plant density 10 -fold shortened the period of growth for yellow starthistle (69 days), but did not effect cheatgrass. Increasing plant density an additional 10 -fold shortened the period of growth for both species to about 60 days.

Density increases tended to shorten the duration of growth of both species (monocultures) with soil depth restrictions of 0.2and $0.5-\mathrm{m}$. At the lowest and highest density, duration of growth was unaffected by soil depth (Table 4). Growth periods were similar for monocultural densities of 1,000 and 10,000 plants $\mathrm{m}^{-2}$ at $0.2-\mathrm{m}$.

\section{Growth of Individuals in Mixtures}

Increasing plant density $(\mathrm{P}=0.0001)$ or decreasing soil depth $(P=0.0001)$ reduced growth rates of both species growing in mixtures. Predicted growth rate (linear model) for isolated individu- als growing in unrestricted soil was about 20 and $103 \mathrm{mg} \mathrm{day}^{-1}$ for cheatgrass and for yellow st:irthistle, respectively (Table 5).

Based upon coefficient ratios, yellow starthistle density was slightly more importint in predicting its growth rate in unrestricted soil than was cheatgrass density. Yellow starthistle and cheatgrass density were of equal value in the prediction of cheatgrass growth rate (Table 5). The duration of yellow starthistle growth was greatest at low starthistle and cheatgrass densities (Table 6).

The predicted growth rate of isolated plants (both species) grown in $0.5-\mathrm{m}$ of soil was greater than $30 \mathrm{mg}$ day $^{-1}$ (Table 5). Cheatgrass density was 1.3 times more important than yellow starthistle density in predicting cheatgrass growth rate. A 10-fold increase in either species reduced yellow starthistle growth rate $4.7 \mathrm{mg} \mathrm{day}^{-1}$.

Predicted growth rate of isolated plants growing in $0.2-\mathrm{m}$ of soil was $3 \mathrm{mg}$ day ${ }^{1}$ (Table 5). Cheatgrass density was about 2 times more important than yellow starthistle density in predicting the growth rate of either species under these conditions.

Based on the time of inflection, increasing the density of either species shortened the duration of growth for yellow starthistle with either a 0.2 - or $0.5-\mathrm{m}$ soil depth (Table 6). The only exception occurred on the $0.2-\mathrm{m}$ soil where yellow starthistle and cheatgrass densities of 1,000 and 100 resulted in a similar duration of growth.

\section{Plant Moisture Stress}

Cheatgrass plants grew with greater (t-test; $P \leq 0.0001$ ) moisture stress than yellow starthistle (-1.27 vs. $-0.71 \mathrm{MPa}$; predawn xylem water potential) in unrestricted soil. Intraspecific interference increased moisture stress in both cheatgrass and yellow starthistle ( $-\mathrm{PP}_{\mathrm{c}}=-1.0-0.11 \log \mathrm{N}_{\mathrm{c}}, \mathrm{R}^{2}=0.25 ;-\mathrm{PP}_{\mathrm{y}}=-0.52-0.1$ $\log N_{\mathrm{y}}, \mathrm{R}^{2}=0.43$ ).

Cheatgrass was under less water stress (t-test; $P \leq 0.05$ ) than yellow starthistle when grown with a $0.5-\mathrm{m}$ soil depth restriction at cheatgrass:starthistle densities of 10:10 (-2.6 vs. $-2.9 \mathrm{MPa})$ and 1,000:10 (-2.4 vs. $-3.3 \mathrm{MPa})$. Regression models for each species

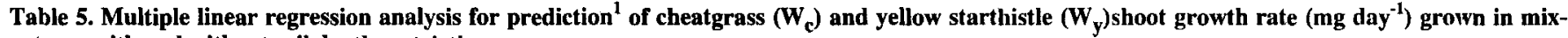
tures with and without soil depth restriction.

\begin{tabular}{|c|c|c|c|c|c|c|}
\hline Species & Soil depth & $\beta_{\mathrm{co}}{ }^{2}$ & $\beta_{c c}$ & $\beta_{c y}$ & $\frac{\text { Coefficient ratio }}{\beta_{c c} / \beta_{c y}}$ & $\mathrm{R}^{2}$ \\
\hline & & $\ldots \ldots$ & (mg day & $\ldots \ldots$ & & \\
\hline \multirow[t]{3}{*}{ Cheatgrass } & Unrestricted & $\begin{array}{l}20.15 \\
(2.70)\end{array}$ & $\begin{array}{l}-2.70 \\
(0.60)\end{array}$ & $\begin{array}{l}-2.80 \\
(0.60)\end{array}$ & 1.0 & 0.55 \\
\hline & $0.5-\mathrm{m}$ & $\begin{array}{l}31.70 \\
(3.80)\end{array}$ & $\begin{array}{l}-4.90 \\
(0.88)\end{array}$ & $\begin{array}{l}-3.90 \\
(0.88)\end{array}$ & 1.3 & 0.6 \\
\hline & $0.2-\mathrm{m}$ & $\begin{array}{c}3.00 \\
(0.44)\end{array}$ & $\begin{array}{l}-0.50 \\
(0.10)\end{array}$ & $\begin{array}{l}-0.24 \\
(0.10)\end{array}$ & 2.1 & 0.47 \\
\hline \multirow[t]{2}{*}{ Starthistle } & Unrestricted & $\begin{array}{l}102.81 \\
(19.30)\end{array}$ & $\begin{array}{r}-16.20 \\
(4.50)\end{array}$ & $\begin{array}{r}-13.30 \\
(4.50)\end{array}$ & 1.2 & 0.40 \\
\hline & $0.5-\mathrm{m}$ & $\begin{array}{l}33.44 \\
(4.80)\end{array}$ & $\begin{array}{l}-4.50 \\
(1.00)\end{array}$ & $\begin{array}{l}-4.90 \\
(1.00)\end{array}$ & 1.1 & 0.52 \\
\hline
\end{tabular}

${ }^{1} W_{c}=\beta_{c o}+\beta_{c c} \log N_{c}+\beta_{c y} \log N_{y}$

$W_{y}=\beta_{y o}+\beta_{y y} \log N_{y}+\beta_{y c} \log N_{c}$

${ }^{2}$ The intercepts $\beta_{c o}$ and $\beta_{y o}$ estimates the growth rate of an isolated plant. Intraspecific interference is measured by the regression coefficient $\beta_{c c}$ or $\beta_{y y}$ ind interspecific interference by $\beta_{\mathrm{cy}}$ or $\beta_{\mathrm{yc}}$. Numbers in parentheses are standard errors for coefficients significantly different from zero. 
Table 6 . Effects of soil depth and plant density on the time of inflection ${ }^{1}$ of cheatgrass and yellow starthistle grown in mixtures.

\begin{tabular}{|c|c|c|c|c|c|c|}
\hline \multirow[b]{3}{*}{ Species } & \multirow{3}{*}{$\begin{array}{l}\text { Soil } \\
\text { depth }\end{array}$} & \multirow{3}{*}{$\begin{array}{l}\text { Yellow } \\
\text { starthistle } \\
\text { density }\end{array}$} & \multirow{2}{*}{\multicolumn{3}{|c|}{$\frac{\text { Cheatgrass density }}{\left(\text { plants } \mathrm{m}^{-2}\right)}$}} & \multirow[b]{3}{*}{$\operatorname{LSD}_{(0.05)}$} \\
\hline & & & & & & \\
\hline & & & 100 & 1,000 & 10,000 & \\
\hline & (m) & (plants $\mathrm{m}^{-2}$ ) & $\ldots$ & - (day & $\ldots . .$. & \\
\hline \multirow[t]{9}{*}{ Cheatgrass } & $\mathrm{UR}^{2}$ & 100 & 72 & 69 & 56 & \\
\hline & & 1,000 & 67 & 64 & 60 & \\
\hline & & 10,000 & 69 & 60 & 60 & NS \\
\hline & 0.5 & 100 & 70 & 59 & 42 & \\
\hline & & 1,000 & 71 & 63 & 44 & \\
\hline & & 10,000 & 51 & 56 & 42 & NS \\
\hline & 0.2 & 100 & 70 & 76 & 47 & \\
\hline & & 1,000 & 70 & 58 & 42 & \\
\hline & & 10,000 & 58 & 66 & 49 & NS \\
\hline \multirow[t]{9}{*}{ Starthistle } & $\mathrm{UR}^{2}$ & 100 & 84 & 77 & 60 & \\
\hline & & 1,000 & 73 & 69 & 65 & \\
\hline & & 10,000 & 71 & 67 & 67 & $9.5^{3}$ \\
\hline & 0.5 & 100 & 84 & 66 & 47 & \\
\hline & & 1,000 & 69 & 59 & 48 & \\
\hline & & 10,000 & 57 & 50 & 44 & $12.3^{3}$ \\
\hline & 0.2 & 100 & 73 & 56 & 45 & \\
\hline & & 1,000 & 74 & 55 & 54 & \\
\hline & & 10,000 & 53 & 52 & 39 & $12.3^{3}$ \\
\hline
\end{tabular}

Time of inflection is considered an indicator of duration of growth.

${ }^{2}$ Unrestricted soil depth.

${ }^{3}$ Comparing density within each depth.

indicate that intra- and interspecific interference increased moisture stress $\left(-\mathrm{PP}_{\mathrm{c}}=-1.87-0.40 \log \mathrm{N}_{\mathrm{c}}-0.54 \log \mathrm{N}_{\mathrm{y}}, \mathrm{R}^{2}=0.56\right.$; $\left.\mathrm{PP}_{\mathrm{y}}=-2.0-0.51 \log \mathrm{N}_{\mathrm{y}}-0.36 \log \mathrm{N}_{\mathrm{c}}, \mathrm{R}^{2}=0.54\right)$ and that yellow starthistle density was most important in both cases. The predicted pressure potential for an isolated cheatgrass and yellow starthistle individual grown in $0.5-\mathrm{m}$ soil was about 2 and 4 times more negative than in unrestricted soil, respectively.

Cheatgrass and yellow starthistle xylem pressure potentials exceeded -5.0 MPa when the soil depth restriction was 0.2-m. The only exception to this observation occurred with cheatgrass at the lowest density combination $(-3.0 \mathrm{MPa})$.

\section{Discussion}

Intraspecific interaction was twice as influencial as interspecific interaction (cheatgrass vs. yellow starthistle) in predicting plant weight on deep soil (Sheley and Larson 1994b, 1995). Results from this study indicate that on deep soil growth rates and duration of growth are influenced by density and may determine the success of the population. At low densities, yellow starthistle grew more rapid, longer and had greater soil depth penetration than cheatgrass. This suggests that infestations containing yellow starthistle and cheatgrass will have increased resource utilization and that the increase will be greatest on deep soils where resource partitioning can be fully developed. However, substituting $\left(10,000\right.$ plants $\left.\mathrm{m}^{-2}\right)$ for the density of yellow starthistle and $(1,000$ plants $\mathrm{m}^{-2}$ ) for cheatgrass density in the equations in Table 5 predicts the growth rate of cheatgrass to be about $4.5 \mathrm{mg} \mathrm{day}^{-1}$, whereas yellow starthistle growth rate would approach zero. This supports the hypothesis that seed production and population dynamics are directing shifts in community dominance (Sheley and Larson 1995).
Talbott (1987) found yellow starthistle dominated deep soils whereas cheatgrass dominated shallow soils. Shallow soils $(0.2-$ $m$ ) reduced both cheatgrass and yellow starthistle growth rates in our study, shifting resource acquisition balance toward cheatgrass and away from the later maturing yellow starthistle. The relatively dry season during this study may have exaggerated our results, but these conditions are predicted to occur 4 times in 10 years.

Suppression of perennial grass seedlings by cheatgrass seedlings has been attributed to growth rate and root system characteristics (Harris 1967, Svejcar 1990, Aquirre and Johnson 1991). Sheley and Larson (1994b) found rooting depth of yellow starthistle was deeper than that of cheatgrass and suggested that differential rooting depth would promote the partition of resources. In this study, the growth rate of yellow starthistle in deep soil was nearly 7 times that of cheatgrass at low densities. We speculate that yellow starthistle has the potential in deep soil to grow faster and sequester more resources than most perennial grass seedlings.

\section{Literature Cited}

Aguirre, L. and D.A. Johnson. 1991. Root morphological development in relation to shoot growth in seedlings of four range grasses. J. Range Manage. 44:341-346.

Callihan, R.H., F.E. Northam, J.B. Johnson, E.L. Michalson, and T.S. Prather. 1989. Yellow starthistle biology and management in pasture and rangeland, University of Idaho. Curr. Inf. Ser. No. 634. Moscow, Lua.

Daubenmire, R. 1970. Steppe vegetation of Washington. Washington Agr. Exp. Sta. Tech. Bull. No. 62.

France, J. and J.H.M. Thornby. 1984. Mathematical models in agriculture. Butterworth and Co. London, England.

Harris, G.A. 1967. Some competitive relationships between Agropyron spicatum and Bromus tectorum Ecol. Monogr. 37:89-111.

Hironaka, M. 1989. Range ecology as the basis for vegetation management, p. 85. In: B.F. Roché, Jr., and C.T. Roché (eds). Range weeds revisited. Coop. Ext. WSU, Misc. 0143. Pullman, Wash.

Hunt, R. 1982. Plant growth curves: The functional approach to plant growth analysis. University Park Press. Baltimore, Minn.

Mack, R.N. 1981. Invasion of Bromus tectorum L. into western North America: An ecological chronicle. Agro-ecosystems. 7:145-165.

Maddox, D.M. and A. Mayfield. 1985. Yellow starthistle infestations are on the increase. Calif. Agr. 39:10-12.

Roché, B.F., Jr., C.T. Roché, and R.C. Chapman. 1994. Impacts of grassland habitat on yellow starthistle (Centaurea solstitialis L.) invasion. Northwest Sci. 68:86-96.

Sheley, R.L. and L.L. J.arson. 1994a. Comparative life-histories of cheatgrass and yellow starthistle growing in association. J. Range Manage. 47:450-456.

Sheley, R.L. and L.I. Larson. 1994b. Comparative growth and interference between cheatgrass and yellow starthistle seedlings. J.Range Manage. 47:470-47.

Sheley, R.L. alud I.L. Larson. 1995. Interference between cheatgrass and yellow starthistle at 3 soil depths. J.Range Manage. 48:392-397.

Sheley, R.L., L.L. I Larson, and D.E. Johnson. 1993. Germination and root dynamics of range weeds and forage species. Weed Technol. 7:234-237.

Sheley, R.L., T.J. Svejrar, and B.D. Maxwell. 1996. A thcoretical framework for developing successional weed mänagement strategies on rangelands, Weed Technol. (In press).

Svejcar, T.J. 1990. Root length, leaf area, and biomass of crested wheatgrass and cheaterass seedlings. J. Range Manage. 43:446-448.

Talbott, C.J. 1987. Distribution and ecological amplitude of selected Centaurea specics in eastern Washington. M.S. Thesis. Washington State University. Pullman, $W /$ ash. 